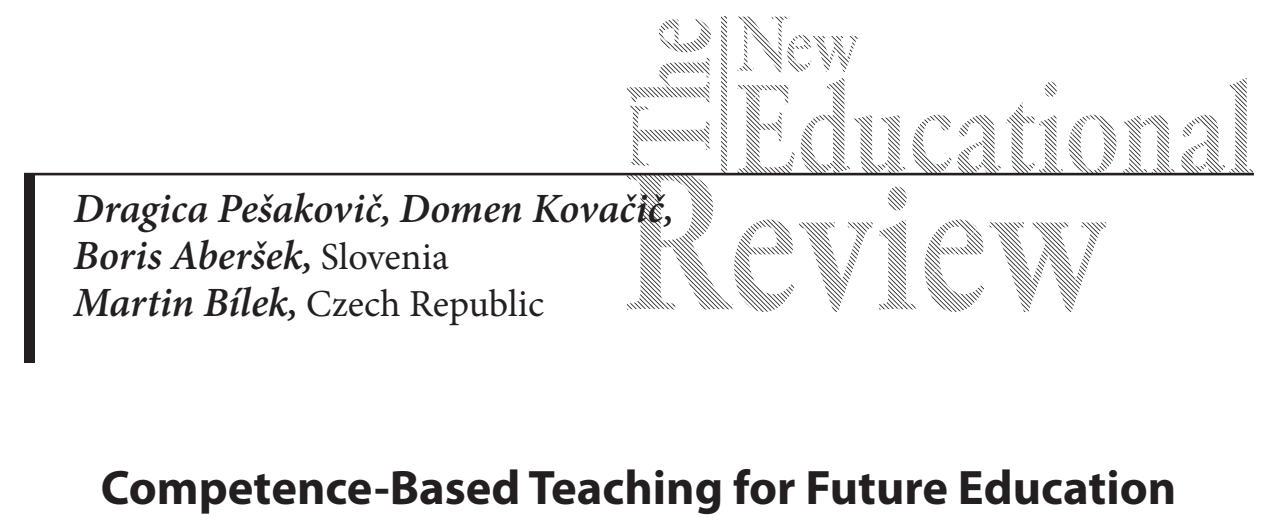

\begin{abstract}
The quality of education is increasingly being measured less by the knowledge gained during schooling and more by the level of competence possessed by students at doing a particular job after completing their education. Target and process-planned curricula are being replaced more and more by competenceoriented curricula, especially in science and technology education, where competences, generally defined as the ability of an individual to do a job properly, are placed at the forefront. In these, skills are not understood primarily as cognitive skills (e.g. critical thinking), but mostly as skills in connection to psychomotorics.

If competence is the desired criterion for educational quality, it can be easily established that suitable instruments and methods of measurement are needed for this kind of quality evaluation, which, however, are not yet available. This is why in the field of competences a special unified competences taxonomy was developed, based on different taxonomies for the cognitive and also affective and psychomotor fields. Additionally, suitable instrumentation was developed in this study. Its use was demonstrated in the example of elementary education in Slovenia in the field of science and technology education.
\end{abstract}

Keywords: quality of education, competences, skills, methods of teaching

\title{
Introduction
}

More and more countries are focusing on measuring and monitoring the quality of education rather than the competiveness of students' knowledge (Kovačič, 2013). One of the certain consequences of a non-competitive education system is high 
unemployment among youth, and the lowering of the general standard of living (Dumont, Istance, Benavides, 2010). These parameters are included in the regular reports made by international organisations such as UNESCO and OECD. Also, the Education for All (EFA, 2011) report "Regional overview: Central and Eastern Europe and Central Asia" emphasises the urgency in raising the competences needed for jobs in the $21^{\text {st }}$ Century (Juszczyk, 2006, Kovačič, 2013, Šimonová, Poulová, Sokolová, Bílek, 2014). Education and the methods of schooling and studying do not provide youth with a competitive advantage, i.e. employability. Therefore, in today's society youth must be equipped with fundamental competences that are general in character (e.g. learning how to learn) and, thus, transferable between different areas. Skills and technical-vocational knowledge must be added to this (UNESCO, 2007, Kovačič, 2013). The results of the Progress in International Reading Literacy Study (PIRLS, 2012) suggest that the model of quality teaching is composed of three fundamental dimensions, where each of them comprises 6 elements:

- Intellectual dimension (Elements: deep knowledge, deep understanding, problematic knowledge, higher-order thinking, meta-language, substantive communication)

- Learning environment (Elements: explicit quality criteria, commitment, high expectations, mutual support, students' self-control, student-teacher joint decisions), and

- Making learning meaningful (Elements: prior knowledge, cultural sophistication, knowledge integration, inclusion, narration).

\section{Research Problem}

The concept of competences has drawn attention to the complexity of knowledge, its entanglement with the disposition of the individual and the need to teach the use of skills (Aberšek, 2012, Pešakovič et al., 2014). Teaching on the basis of competences should take place at all stages of the teaching process. Competence diagnostics, through which teachers and students can find out to what degree an individual's competence is developed, plays a vital part, which has led to the development of a competitive model as a diagnostic instrument (Upheus, 2010). As noted by R. Wesselink "the design of a competence-based curriculum, the design of the learning process and the design process of evaluation can be performed only when the concept of competences is defined as clearly as possible. Another great trap is assessment, which is viewed as the Achilles heel of competence-based learning" (Wesselink et al., 2007: 39). 
Knowledge and attitudes (Bloom, 1956, Anderson, Krathwohl, 2001) can be measured with standardised tests. Attitudes can also be assessed by using standardised procedures, such as the Thurstone, Likert (Judd, Smith, Kidder, 1991) or Bogardus scales (Miller, 1991). A problem in assessing skills especially psychomotor skills arises when there are no standardised tests (Pešakovič, 2014).

Figure 1. Unified taxonomy of competences

\begin{tabular}{|c|c|c|c|c|c|}
\hline & Domains & \multicolumn{2}{|c|}{ Lower levels } & \multicolumn{2}{|c|}{ Higher levels } \\
\hline $\begin{array}{l}\text { Bloom cognitive } \\
\text { taxonomy }\end{array}$ & Cognitive & \multicolumn{2}{|c|}{$\begin{array}{l}\text { Knowledge } \\
\text { Comprehension } \\
\text { Application }\end{array}$} & \multicolumn{2}{|c|}{$\begin{array}{l}\text { Analysis } \\
\text { Evaluation } \\
\text { Synthesis }\end{array}$} \\
\hline $\begin{array}{l}\text { Bloom affective } \\
\text { taxonomy }\end{array}$ & Affective & \multicolumn{2}{|c|}{$\begin{array}{l}\text { Receiving } \\
\text { Responding }\end{array}$} & \multicolumn{2}{|c|}{$\begin{array}{c}\text { Valuing } \\
\text { Organizing } \\
\text { Characterizing }\end{array}$} \\
\hline $\begin{array}{l}\text { Taxonomy for psycho- } \\
\text { motor domain - Dave } \\
\text { taxonomy }\end{array}$ & \multirow{2}{*}{ Psychomotor } & \multirow{2}{*}{$\begin{array}{l}\text { Dave } \\
\text { Imitate } \\
\text { Manipulate }\end{array}$} & \multirow{2}{*}{$\begin{array}{l}\text { Simpson } \\
\text { Perception } \\
\text { Set } \\
\text { Guided } \\
\text { response } \\
\text { Mechanism }\end{array}$} & \multirow{2}{*}{$\begin{array}{l}\text { Dave } \\
\text { Perfect } \\
\text { Articulate } \\
\text { Embody }\end{array}$} & \multirow{2}{*}{$\begin{array}{c}\text { Simpson } \\
\text { Complex overt } \\
\text { response } \\
\text { Adaptation } \\
\text { Origination }\end{array}$} \\
\hline $\begin{array}{l}\text { Taxonomy for psycho- } \\
\text { motor domain - } \\
\text { Simpson taxonomy }\end{array}$ & & & & & \\
\hline \multicolumn{6}{|c|}{ Unified taxonomy f competences } \\
\hline \multicolumn{2}{|c|}{ Lower level } & \multicolumn{4}{|c|}{ Higher level } \\
\hline \multicolumn{2}{|c|}{$\begin{array}{l}\text { - Perception and imitating the teacher } \\
\text { connected with affective domain - } \\
\text { receiving and responding. } \\
\text { - Set and guided response connected } \\
\text { with cognitive activities as knowl- } \\
\text { edge and comprehension. } \\
\text { - Mechanism connected with cogni- } \\
\text { tive application and collaboration } \\
\text { (collaborative teaching/learning). }\end{array}$} & \multicolumn{4}{|c|}{$\begin{array}{l}\text { - Complex overt response based on cognitive analysis and } \\
\text { evaluation. } \\
\text { - Modification and developing new activities based on analy- } \\
\text { sis, evaluation and social responsibility (affective valuing } \\
\text { and organizing) - responsibility to others, responsibility to } \\
\text { society, ecological responsibility, etc. } \\
\text { - Adaptation and origination, new activities taking into ac- } \\
\text { count synthesis of knowledge and characterizing responsi- } \\
\text { bility. }\end{array}$} \\
\hline
\end{tabular}

It was also established that it is very difficult to use only one taxonomy for evaluating competences. Therefore a taxonomy was developed in our research that covers the cognitive and affective fields, and the taxonomies of R.H. Dave, E. Simpson and A. Harrow that cover the psychomotor field (Aberšek, 2012). It was named Unified Taxonomy of Competences (UTC) and symbolically presented in Figure 1.

\section{Research focus}


Why is the concept of taxonomies and competences so important nowadays in the process of education? The answer is simple. We are not interested only in how much students know, but also which competences and skills they hold. It is important how they understand the acquired knowledge, how they use it in new situations and how they solve problems. Students should obtain results with their own activities, research and discoveries, i.e. by the constructive path. By using taxonomies we determine the amount and quality of knowledge, and by using competences the combination of knowledge, skills and experiences that are needed to solve problems in everyday situations. How to implement and evaluate classes that would suite these demands is the fundamental research focus of this study.

\section{Research Methodology}

\section{Research General Background}

Special methods and instruments were developed for the evaluation of students' competences on the basis of a unified taxonomy of competences in this research. The research was carried out in two consecutive school years, 2011/2012 and $2012 / 2013$. In the $2011 / 2012$ school year the first study was carried out and was used to verify the basic measurement characteristics of the test and the selected instrument, the so-called recording form (cf., Table 1). The recording form was used by an external expert to grade (circle) the level of mastering a specific skill at both the lower and higher UTK levels. Students were divided into two groups, the experimental (EG) and the control group (CG). Work in the EG was project-based and included problem-based and research-based lessons. In the control group the lessons were taught conventionally, with a teacher providing explanations and teaching in front of the classroom, and working with textbooks. The study was performed in order to verify the validity, reliability, objectivity and sensitivity of the recording form. On the basis of this preliminary pilot study and a comprehensive analysis of the instruments used and the learning process it was established that the study could continue.

The second study was carried out in the 2012/2013 school year. At this stage of the study the emphasis was put on developing and assessing students' skills. The procedure was identical to that at the preceding stage.

All research was done in the frame of subject design and technology. 


\section{Research Sample}

In the $2011 / 2012$ school year the study included 38 students from the $6^{\text {th }}$ grade of elementary school, aged between 10 and 11 . They were randomly divided into two groups, the CG (20 students) and the EG (18 students). The research sample included approximately the same number of boys and girls.

The second study was carried out in the 2012/2013 school year. The study comprised 35 students also from the $6^{\text {th }}$ grade. They were randomly selected and divided into two groups, the CG (18 students) and the EG (17 students). There were a third as many boys in the research sample as girls. Because the sample is relatively small (because the tests school is small) the statistical validation of the results was used.

\section{Instruments and Procedures}

A recording form (Table 1) was used for direct observation of the students' skills in carrying out a specific task. The name of the competence was written in the form title field (Pešakovič, 2014).

Table 1. Example of a recording form

\begin{tabular}{l} 
Competence: ABILITY TO INTERPRET INFORMATION \\
\hline SKILLS: \\
- Presentation of information in a clear manner, correct use of professional terms; \\
- Preparation and presentation of a project (work plan, seminar or poster).
\end{tabular}

HOW? Observe the skills of the particular student and circle the relevant level of skill mastery.

Pay attention to whether information is presented clearly and accurately, and whether the student prepared the project independently.

\begin{tabular}{|c|c|c|c|c|c|c|}
\hline \multirow{3}{*}{ 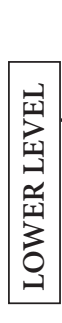 } & CRITERION & \multicolumn{5}{|c|}{ MASTERY OF SKILL } \\
\hline & $\begin{array}{l}\text { In their presentation the student reviewed already known } \\
\text { facts and concepts. The project was not elaborated on; other } \\
\text { students could not discern the point. }\end{array}$ & 1 & 2 & 3 & 4 & 5 \\
\hline & $\begin{array}{l}\text { The student presented the information in a clear way and } \\
\text { reported independently using professional terms yet phrased } \\
\text { in the student's own words. The project was elaborated on } \\
\text { and summarised the essential points. }\end{array}$ & 1 & 2 & 3 & 4 & 5 \\
\hline 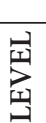 & $\begin{array}{l}\text { The student analysed the information presented and provided } \\
\text { argumentation for it. The project included all key elements } \\
\text { required. }\end{array}$ & 1 & 2 & 3 & 4 & 5 \\
\hline 趉 & $\begin{array}{l}\text { Key elements were connected in the presentation. The stu- } \\
\text { dent independently formed clear conclusions that were cor- } \\
\text { rect and reliable. The student's own ideas were dominant. The } \\
\text { student evaluated their project and suggested improvements. }\end{array}$ & 1 & 2 & 3 & 4 & 5 \\
\hline
\end{tabular}


That was followed by a definition of the observed skill, how the skill was observed and what had to be taken into account. These could be adapted to the individual subject and thematic area. The observer had to circle the degree of control, where 1 meant unsatisfactory, 2 satisfactory, 3 good, 4 fairly good and 5 very good mastery of the skill.

\section{Procedure}

In this research two methods were used, namely a triangulation method and a qualitative educational research method. The purpose of triangulation in qualitative research is to increase the credibility and validity of the results (Pešakovič, et al., 2014). In this case triangulation was used to observe the process and verify the students' attainment of skills. This ensured that the research situation could be observed from three perspectives: the teacher, the performer/student and observer. The observer was an expert in the field of technical education. The method of direct observation was used.

In the EG, project-based learning (PBL) and research-based learning (RBL) was used. The training and demonstration of certain skills were conducted. In the CG, a frontal teaching method was used, e.g. conversation, demonstration and work with texts.

The instrument and measurement methodologies developed enabled the optimisation of the learning process; different methods of work were assessed depending on the given objectives with a focus on student skills.

\section{Data Analysis}

The data was computer processed using the SPSS 20.0 program for statistical analysis, at the descriptive and inferential statistics levels. The following procedures were used:

- frequency distributions (f, f\%) of descriptive variables;

- $\chi^{2}$-test of the hypothesis of independence to test dependent associations between variables (according to gender and the final grade in Science and Technology);

- t-test for verifying hypotheses in smaller samples (progress dependent on gender and final grade). 


\section{Research Results}

We checked the mastery of skills before and after class. The results were compared with both groups, the boys and girls, and were connected to knowledge and skills at the end of the $5^{\text {th }}$ class in subject Science and Technology. The results of the comparison are stated below. The next analysis shows the difference between the initial and final states of mastering certain skills of a student at a lower and higher UTK taxonomical level and his/her progress.

\section{Mastering skills before and after the experiment in the experimental group}

Table 2. The results of t-test for the dependent patterns for evaluating differences between initial and final mastery according to the student's gender

\begin{tabular}{|c|c|c|c|c|c|}
\hline & & $\begin{array}{c}\text { Arithmetic } \\
\text { mean }\end{array}$ & $\begin{array}{l}\text { Differences } \\
\text { of arithmetic } \\
\text { mean }\end{array}$ & \multicolumn{2}{|c|}{$\begin{array}{l}\text { Test for difference of } \\
\text { arithmetic means }\end{array}$} \\
\hline \multicolumn{2}{|l|}{ Skills/competences } & $\bar{x}$ & $\bar{x}_{\mathrm{i}}-\bar{x}_{\mathrm{f}}$ & $t$ & $\mathbf{P}$ \\
\hline \multirow[t]{2}{*}{ Total lower level Boys } & Initial. & 2.649 & -1.454 & -24.176 & 0.000 \\
\hline & Final. & 4.103 & & & \\
\hline \multirow[t]{2}{*}{ Total lower level Girls } & Initial. & 3.494 & -1.380 & -8.971 & 0.000 \\
\hline & Final. & 4.875 & & & \\
\hline \multirow[t]{2}{*}{ Total higher level Boys } & Initial. & 1.733 & -1.383 & -12.039 & 0.000 \\
\hline & Final. & 3.116 & & & \\
\hline \multirow[t]{2}{*}{ Total higher level Girls } & Initial. & 2.666 & -1.750 & -14.685 & 0.000 \\
\hline & Final. & 4.416 & & & \\
\hline \multirow[t]{2}{*}{ Total Boys } & Initial. & 2.191 & -1.418 & -20.560 & 0.000 \\
\hline & Final. & 3.610 & & & \\
\hline \multirow[t]{2}{*}{ Total Girls } & Initial. & 3.080 & -1.565 & -12.335 & 0.000 \\
\hline & Final. & 4.645 & & & \\
\hline
\end{tabular}

The test of arithmetic mean differences showed (Table 3 ) that there is a statistically typical difference $(\mathrm{P}<0.005)$ between the boys and the girls between the final and initial states in mastering skills at the lower and higher taxonomical levels. This difference and progress in mastering a certain skill according to gender is shown in Figure 2. 
Figure 2. Initial state and progress in mastering skills in the experimental group, before and after the experiment, according to gender

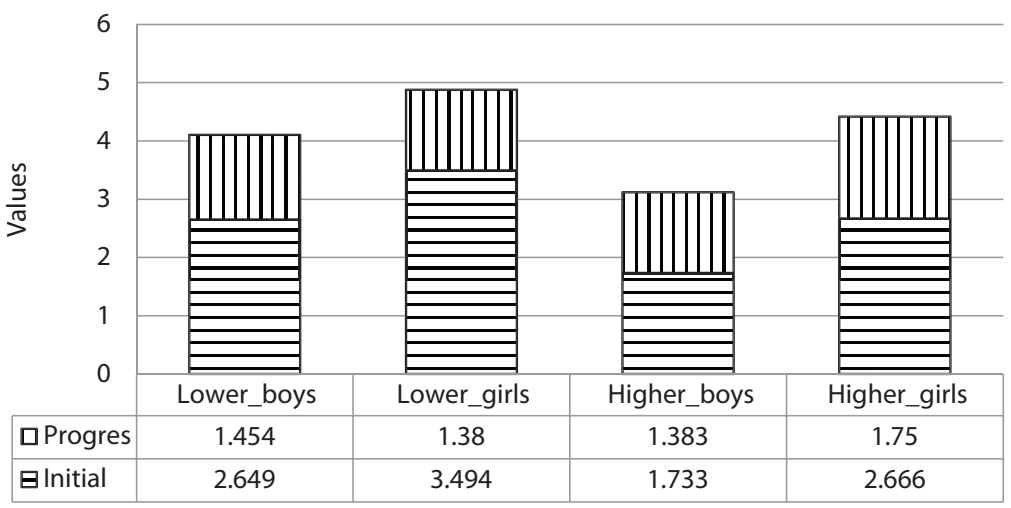

\section{Mastering the skills according to the final grade in the experimental group}

Table 3. The results of t-test for the dependent patterns for evaluating differences between initial and final mastery of a skill according to the final grade in the subject Science and Technology

\begin{tabular}{|c|c|c|c|c|c|}
\hline \multirow{2}{*}{ Skills - marks (1-5) } & & \multirow{2}{*}{$\begin{array}{c}\begin{array}{c}\text { Arithmetic } \\
\text { mean }\end{array} \\
\bar{x}\end{array}$} & \multirow{2}{*}{$\begin{array}{c}\begin{array}{c}\text { Differences of } \\
\text { arithmetic mean }\end{array} \\
\bar{x}_{\mathrm{i}}-\bar{x}_{\mathrm{f}}\end{array}$} & \multicolumn{2}{|c|}{$\begin{array}{l}\text { Test for difference of } \\
\text { arithmetic means }\end{array}$} \\
\hline & & & & $\mathrm{t}$ & $\mathrm{P}$ \\
\hline \multirow[t]{2}{*}{ lower_good (3) } & Initial. & 2.435 & -1.457 & -14.858 & 0.001 \\
\hline & Final. & 3.892 & & & \\
\hline \multirow[t]{2}{*}{ lower_fairly good (4) } & Initial. & 2.707 & -1.435 & -14.450 & 0.000 \\
\hline & Final. & 4.142 & & & \\
\hline \multirow[t]{2}{*}{ lower_very good (5) } & Initial. & 3.484 & -1.403 & -10.632 & 0.000 \\
\hline & Final. & 4.887 & & & \\
\hline \multirow[t]{2}{*}{ higer_good (3) } & Initial. & 1.557 & -1.157 & -6.240 & 0.001 \\
\hline & Final. & 2.714 & & & \\
\hline \multirow[t]{2}{*}{ higer_fairly good (4) } & Initial. & 1.714 & -1.514 & -15.221 & 0.000 \\
\hline & Final. & 3.228 & & & \\
\hline \multirow[t]{2}{*}{ higer_very good (5) } & Initial. & 2.673 & -1.765 & -17.329 & 0.000 \\
\hline & Final. & 4.438 & & & \\
\hline \multirow[t]{2}{*}{ TOTAL good (3) } & Initial. & 1.996 & -1.307 & -12.244 & 0.000 \\
\hline & Final. & 3.303 & & & \\
\hline
\end{tabular}




\begin{tabular}{|c|c|c|c|c|c|}
\hline \multirow{2}{*}{ Skills - marks (1-5) } & & \multirow{2}{*}{$\begin{array}{c}\begin{array}{c}\text { Arithmetic } \\
\text { mean }\end{array} \\
\bar{x}\end{array}$} & \multirow{2}{*}{$\begin{array}{c}\begin{array}{c}\text { Differences of } \\
\text { arithmetic mean }\end{array} \\
\bar{x}_{\mathrm{i}}-\bar{x}_{\mathrm{f}}\end{array}$} & \multicolumn{2}{|c|}{$\begin{array}{l}\text { Test for difference of } \\
\text { arithmetic means }\end{array}$} \\
\hline & & & & $t$ & $\mathrm{P}$ \\
\hline \multirow{2}{*}{$\begin{array}{l}\text { TOTAL fairly good } \\
\text { (4) }\end{array}$} & Initial. & 2.210 & -1.475 & -17.586 & 0.000 \\
\hline & Final. & 3.685 & & & \\
\hline \multirow{2}{*}{$\begin{array}{l}\text { TOTAL very good } \\
\text { (5) }\end{array}$} & Initial. & 3.079 & -1.584 & -14.550 & 0.000 \\
\hline & Final. & 4.663 & & & \\
\hline
\end{tabular}

The test of arithmetic mean differences showed that there is also a typical statistical difference $(\mathrm{P}<0.05)$ between the final and initial states in mastering skills at the lower and higher levels in the EG. This difference, according to the final grade in the subject Science and Technology, in shown in Figure 3.

Figure 3. Initial state and progress according to the final grade in the subject Science and Technology

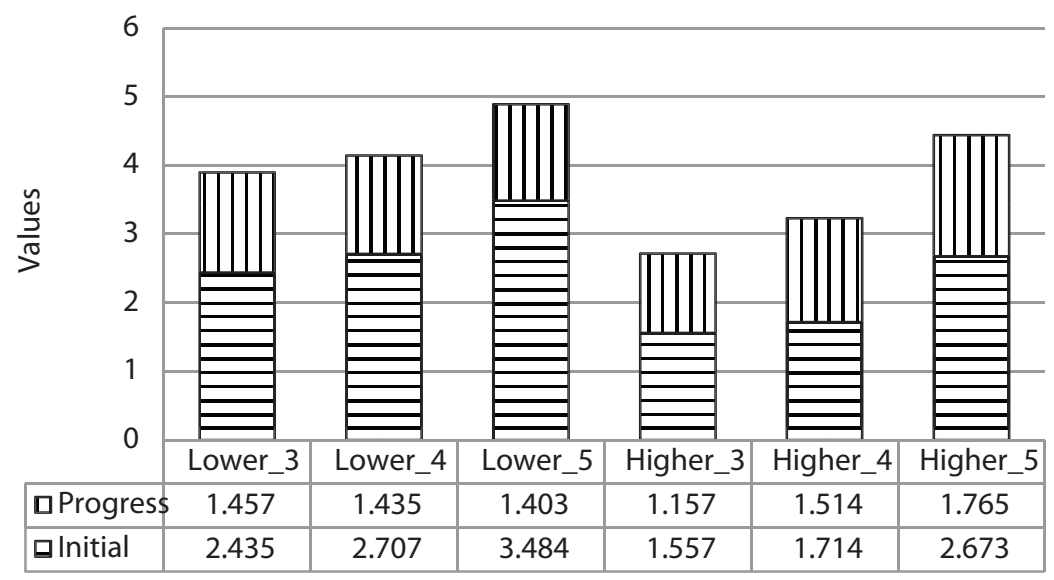

\section{Mastering skills before and after the experiment according} to the group

The results for the CG could be shown similarly. We shall focus only on the comparison between them. The test of arithmetic mean differences (Table 4) showed that according to the group there is also a typical statistical difference $(\mathrm{P}<0.05)$ between the final and initial states in mastering skills at the lower and higher taxonomical levels. 
Table 4. The results of t-test for the dependent patterns for evaluating differences between initial and final mastery of a certain skill according to the group

\begin{tabular}{|c|c|c|c|c|c|}
\hline \multirow[b]{2}{*}{ Skills } & & \multirow{2}{*}{$\begin{array}{c}\begin{array}{c}\text { Arithmetic } \\
\text { mean }\end{array} \\
\bar{x} \\
\end{array}$} & \multirow{2}{*}{$\begin{array}{c}\begin{array}{c}\text { Differences of } \\
\text { arithmetic mean }\end{array} \\
\bar{x}_{\mathrm{i}}-\bar{x}_{\mathrm{f}}\end{array}$} & \multicolumn{2}{|c|}{$\begin{array}{c}\text { Test of difference of } \\
\text { arithmetic means }\end{array}$} \\
\hline & & & & $t$ & $\mathrm{P}$ \\
\hline \multirow[t]{2}{*}{ lower_EG } & Initial. & 2.947 & -1.428 & -22.163 & 0.000 \\
\hline & Final. & 4.376 & & & \\
\hline \multirow[t]{2}{*}{ lower_CG } & Initial. & 2.797 & -0.775 & -21.058 & 0.000 \\
\hline & Final. & 3.573 & & & \\
\hline \multirow[t]{2}{*}{ higher_EG } & Initial. & 2.063 & -1.512 & -14.665 & 0.000 \\
\hline & Final. & 3.575 & & & \\
\hline \multirow[t]{2}{*}{ higher_CG } & Initial. & 1.861 & -0.174 & -5.095 & 0.008 \\
\hline & Final. & 2.035 & & & \\
\hline \multirow[t]{2}{*}{ TOTAL_EG } & Initial. & 2.505 & -1.470 & -23.050 & 0.000 \\
\hline & Final. & 3.975 & & & \\
\hline \multirow[t]{2}{*}{ TOTAL_CG } & Initial. & 2.329 & -0.475 & -15.690 & 0.000 \\
\hline & Final. & 2.804 & & & \\
\hline
\end{tabular}

The differences in mastering the skill at the beginning and the progress can be seen in Figure 4.

Figure 4. Initial mastery of the skill and the progress - as a group

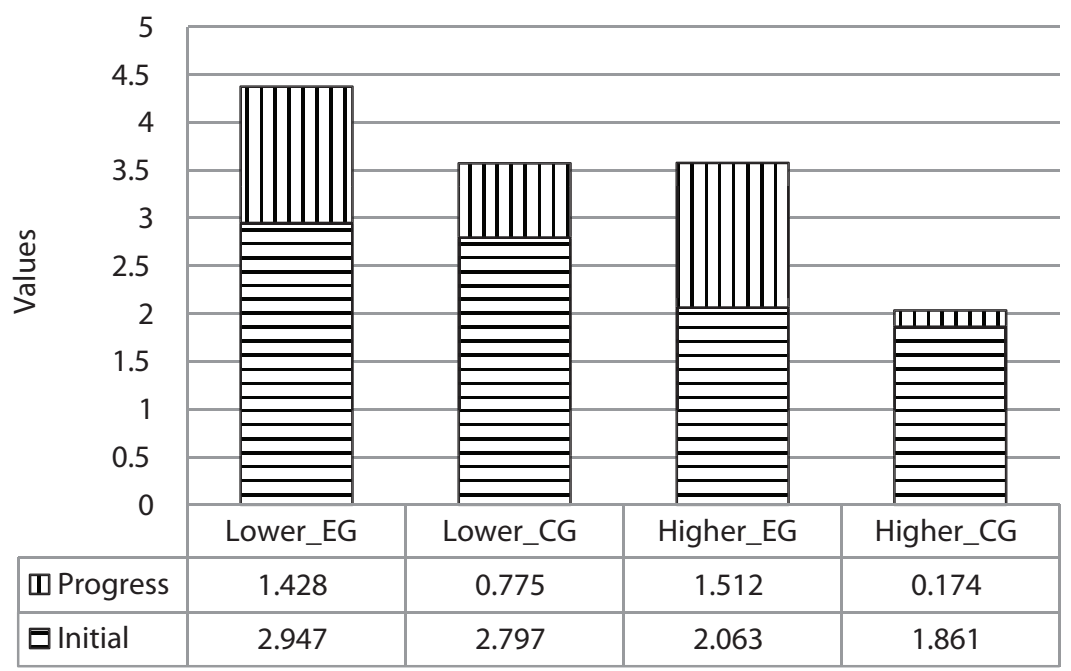


The effect size (d) was measured by deducing the average transfer grade in the control group from the average transfer grade in the experimental group. This was then divided by the combined standard deviation. According to Cohen (2009), the effect size of +0.8 is large, +0.5 medium and +0.2 small, which is why planning principles with effect size 0.8 or more are of particular interest.

Table 5. Effect size

\begin{tabular}{lccccc}
\hline \multicolumn{5}{c}{ AVERAGE VALUE } \\
\hline & $\begin{array}{c}\text { Control } \\
\text { group (CG) }\end{array}$ & $\begin{array}{c}\text { Experimental } \\
\text { group (EG) }\end{array}$ & $\begin{array}{c}\text { Combined stand- } \\
\text { ard deviation }\end{array}$ & Result \\
\hline & Lower level & 3.677 & 4.425 & 1.099 & $\mathbf{0 . 6 8}$ \\
\cline { 2 - 6 } & Higher level & 2.322 & 3.614 & 2.105 & $\mathbf{0 . 6 1}$ \\
\hline $\begin{array}{l}\text { AVERAGE } \\
\text { VALUE }\end{array}$ & 2.999 & 4.019 & 1.602 & $\mathbf{0 . 6 4}$ \\
\hline
\end{tabular}

\section{Discussion}

Planning lessons well is very important for the teacher since this is the only way to achieve the desired progress in students (Cohen, 2009). This research mainly focused on developing and evaluating students' skills. A large part of lesson planning is the knowledge of all the competences and the specifics of each individual competence, especially which strategies, methods and types of lessons are being planned, since they fundamentally affect the development of a certain skill or competence. To sum up all the major findings presented in the research:

1. The progress in mastering a skill at both UTC taxonomical levels together depends on the student's gender. The boys achieved better progress in mastering skills at a taxonomical level lower than the girls. Additional attention must be paid to developing skills in the boys at a higher taxonomical level, especially in the area of communicational skills where the boys achieved fairly lower progress than the girls. They were, however, more skilful in practical tasks.

2. The progress in mastering a skill at both taxonomical levels together also depends on the final grade in the subject Science and Technology in the $5^{\text {th }}$ grade. The students with a higher final grade achieved in the $6^{\text {th }}$ grade better progress than the students with a lower final grade. Because of this the students with a lower grade need to receive more attention in developing skills, especially at a higher taxonomical level. 
3. The differences in the progress on mastering skills at both UTC taxonomical levels are also between the EG and the EC. In this research it was proven that in project work based on problem-based and research-based lessons (active students), better results were achieved in developing the students' skills than with frontal work (students are passive listeners).

That project based learning, which encompasses problem-based lessons, experimental and research work, and has a very strong effect on students' process knowledge and indirectly on developing skills, is also proven by John Hattie's results, who sieved through 900 results of meta-analysis, which included 52600 studies and 240000 students (Hattie, 2013). He established that PBL has a strong effect (above 0.60 ) on students' achievement and also on cooperative learning, developing vocabulary, teaching learning strategies, solving problems and students' prior achievements (prior knowledge). These are also the elements that we planned when implementing lessons and research. In our research even slightly better results were obtained, the average value of the effect size was 0.64 (cf., Table 5).

\section{Conclusions}

The results showed that project-based learning as a modern teaching method and part of the competence-based curriculum offers optimum development of students' knowledge and skills. Not only is it important to develop certain skills, i.e. competences, but one also needs to have suitable tools to test them. On the basis of Bloom's, Simpson's and Dave's taxonomies for all three fields, cognitive, affective and psychomotor, the research developed a unified taxonomy of competences (UTC) where acquired skills/competences in every field at a lower and higher taxonomical levels are defined. For this purpose, instrumentation for measuring students' skills/competences was developed.

The research was carefully planned, because it took place in a classroom with randomly chosen students in the presence of experts from the technical and pedagogical-didactical fields. The developed instrumentation allowed for evaluation of initial and final mastery of skills at both UTC taxonomical levels, and following the progress in mastering skills.

We hope that the results of our research will be of great help to teachers, as the instrumentation developed along with the measurement methodology will help improve the quality of examination and evaluation of students' skills, not only in Science and Technology, but also in other areas of education, and not only in Slovenian schools, but also worldwide. The results and findings of this research 
could also have an impact on the consideration of amending the regulations on examination and assessment of knowledge in elementary school and integrating assessment of student skills.

\section{References}

Aberšek, B. (2012). Didaktika tehniškega izobraževanja med teorijo in prakso, [Didactic of Science and Technology Education between Theory and Practice]. Ljubljana: Zavod RS za šolstvo.

Anderson, L.W., Krathwohl, D.R. (Eds.). (2001). A taxonomy for learning, teaching and assessing: A revision of Bloom's Taxonomy of educational objectives: Complete edition. New York: Longman.

Bloom, B.S. (1956). Taxonomy of educational objectives. Boston, MA: Allyn and Bacon, Copyright (c) 1984 by Pearson Education.

Bogdan, R.C., Biklen, S.K. (2006). Qualitative research in education: An introduction to theory and methods. Boston. MA: Allyn and Bacon.

Cohen, J. (2009). Statistical power analysis for the behavioral sciences. New York, London: Psychological Press, Taylor and Francise Group, Newe Group.

Dumont, H., Istance, D., Benavides, F. (2010). The nature of learning, Using research to inspire practice. Paris: OECD.

EFA (2011). Regional overview: Central and Eastern Europe and Central Asia report. Retrived 15.06.2014 from www.unesdoc.unesco.org/images/0019/0019 17/191765e.pdf

Hieber, U., Lenz, T., Stengelin, M. (2011). Brennpunkt Klassenarbeit. Geographie heute, No. 32, 30-32.

Judd, C.M., Smith, E.R., Kidder, L.H. (1991). Research methods in social relations. Forth Worth: Holt, Rinehart and Winstion Inc.

Juszczyk, S. (2006). Education in the Knowledge-based Society - Chosen Aspects. The New Educational Review, Vol. 10 (2-4), pp. 15-32.

Kovačič, D. (2013). Kompetenčni profil ravnateljev osnovne šole $v$ Sloveniji, (PhD. disertation in Slovene). Kranj: University of Maribor, Faculty for Organization.

Miller, D.C. (1991). Handbook of research design and social measurement. London: Sage.

Pešakovič, D., Flogie, A., Aberšek, B. (2014) Development and Evaluation of a Competence-Based Teaching Process for Science and Technology Education. Journal of Baltic Science Education, 13 (5), 740-755. 
Pešakovič, D. (2014) Razvijanje in preverjanje spretnosti učencev z različnimi metodami pouka $v$ kompetenčno zasnovanem kurikulumu, (PhD. disertation in Slovene). Maribor: University of Maribor, Faculty of Natural Science and Mathematics

PIRLS (2012) International Results in Reading, Boston: International Study Center, Boston College. Retrived 15.06.2014 from http://timssandpirls.bc.edu/

Šimonová, I., Poulová, P., Sokolová, M., Bílek, M. On Forming Key Competences within the ICT-Supported Instruction in Higher Education. The New Educational Review, Vol. 35 (1), pp. 134-150.

UNESCO (2007) Education for All by 2015, Will we make it? Paris: UNESCO.

Upheus, R. (2010). Gute theorie ist praktisch. Kompetenzorientiert unterrichten im Fach Geographie. Magazin Geographie, No. 3, 8-12.

Wesselink, R. Biemans, H.J.A; Mulder, M., van de Elsen, E.R. (2007). Competencebased VET as seen by Dutch researhers. European journal of vocational training, Vol. 40, No. 1, 38-51. 